\title{
Indoor Parking: Architecture of a New Approach to Parking and Vehicle Location
}

Antonio Ferreira de Oliveira Neto a; Herman A. Lepikson, Dr.Eng. ${ }^{b}$, Mário Augusto Santana de Oliveira Júnior ${ }^{c}$.

a Programa de Pós-Graduação em Mecatrônica, UFBA, Salvador/Bahia, Brazil, antoniofon14@gmail.com.

b Programa de Pós-Graduação em Gestão e Tecnologia, Senai Cimatec,

Salvador/Bahia,Brazil, Herman.Lepikson@fieb.org.br.

c Programa de Pós-Graduação em Mecatrônica, UFBA, Salvador/Bahia, Brazil, mario_augusto@outlook.com.

\begin{abstract}
The location of spaces in large parking lots, as well as the vehicle parked when returning, have always been problems for users. There are already solutions for open parking, thanks to GPS and mobile communication. However, this is still an unsolved problem when it comes to indoor parking. This study aimed to identify how the architectures of intelligent parking systems are being built for covered environments. Search was carried out in the literature review, with careful evaluation regarding the relevance and the technologies used in the construction of those systems. Thus, it was possible to analyze the architectures proposed in the related works were analyzed and indicate a new architecture based on the existing gaps.
\end{abstract}

Keywords: Smart Parking; Indoor Parking; Internet of Things; Location and Identification.

\section{Estacionamento interno: arquitetura de uma nova abordagem para localização de vagas e veículos}

Resumo: A localização de vagas em grandes estacionamentos, bem como do veículo estacionado quando do retorno, sempre foram problemas para os usuários. Já existem soluções para estacionamentos abertos, graças ao GPS e à comunicação móvel. Entretanto, este é ainda um problema mal resolvido quando se trata de estacionamentos internos. Este estudo visou identificar como estão sendo construídas as arquiteturas dos sistemas para estacionamentos em ambientes cobertos. Realizouse busca na revisão da literatura, com avaliação criteriosa quanto à relevância e às tecnologias empregadas na construção dos sistemas. Assim, pôde-se analisar as arquiteturas propostas nos trabalhos correlatos e indicar uma nova arquitetura baseada nas lacunas existentes.

Palavras-Chave: Estacionamentos Inteligentes; Estacionamentos Internos; Internet das Coisas; Localização e Identificação. 


\section{INTRODUÇÃO}

A recurring theme and currently in evidence, treated with great expectation and relevance in academia, is the internet of things. Given the scope of its applications, it is inserted in contexts of the most varied of society, such as: industrial, commercial and residential [1].

One of the aspects of the development of processes associated with the Internet of Things is the creation of systems for smart parking, which interact with users, particularly in the addressing problem and managing spaces, in order to facilitate the finding of a place to park your automobile in a commercial establishment [2].

[3] claim that innovations for smart parking have started to be treated with relevance by large urban centers and technological development. Also according to [3], the creation of appropriate methods and systems to interact with customers in a commercial establishment or public place generates greater convenience for drivers. Nowadays, intelligent interaction systems are aimed at urban parking management applications, even if they have a private parking management bias. As noted, one of the alternatives for using smart parking is the association of technologies that integrate the communication between servers and sensors in order to generate data that can be used by managers and users.

When considering that management systems for smart parking lots are used to reduce the time spent to find an available parking space, [4] they say that jobs dealing with smart parking seek to defend or inform about technology choices that will assist drivers in parking.

When the topic to be treated is closed indoor parking, the focus of the current research, there are some contributions that are dedicated to orient the driver, through various applications and the available parking space. However, it is still difficult to find researches that guide the user to find his vehicle the moment he returns to the parking lot. The subjacent problem is related to the unavailability of access to GPS in this type of parking.

In this context, greater integration between the parking system with the user should be promoted, through devices capable of communicating between the parking database with the user's mobile device [6]. It is necessary to observe the intrinsic characteristics of the location, energize the data analysis, promote information that guides the user to the parking space, initially indicated by the parking system, besides to considering the return of the customer to the place where he parked the vehicle [5].

The present research describes a smart parking architecture that allows its interaction with the user to allow the tracking of the active (vehicle or person) for parking to and from the vehicle already parked. It is used the generation of frequency maps, identification and alteration of the parking space status (occupied / available) and server / user communication. 


\section{METHODOLOGY}

For the development of this work, academic text search platforms were used to guide the choice of those whose themes are in line with the use of intelligent parking systems for covered environments linked to the internet of things approach, using the keywords in English shown in figure 1. The main databases used were Google Scholar, ScienceDirect by Elsevier, SciELO - Scientific Electronic Library Online and IEEE Xplorer Digital Library.

Figure 1. Search keywords. Prepared by the authors.

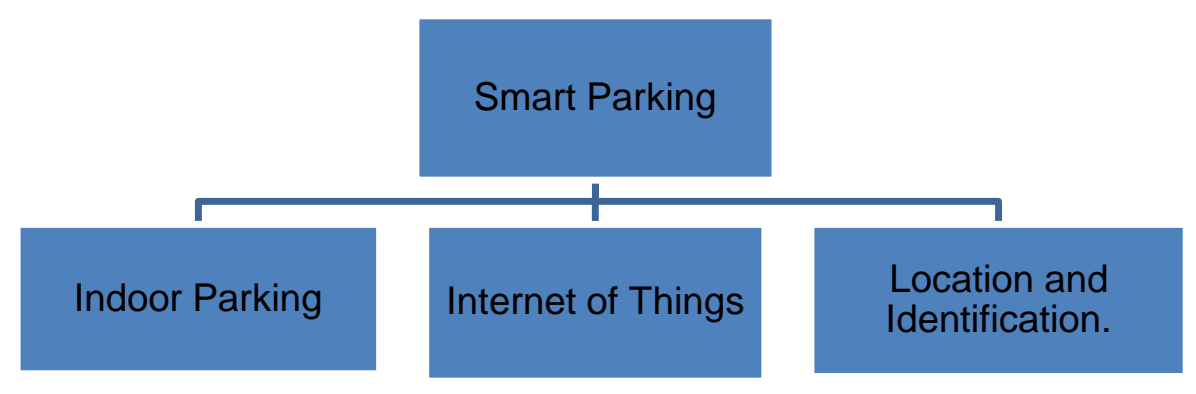

After searches realization, criteria were used to evaluate and choose the articles that enable the best conceptual framework for the development and validation of the proposed architecture. Still, such criteria become necessary to help the exclusion of works that have different development characteristics of interest from those surveyed. Thus, the criteria for approval of the articles covered were: time equal or less than 7 years of publication, use of two of the keywords designated in the research in their development and convergence with the theme of smart parking systems for covered / closed environments. Table 1 below shows the articles that contribute to the development of the research work.

Table 1. Basis for selecting related works. Prepared by the authors.

\begin{tabular}{|l|c|c|c|}
\hline \multicolumn{1}{|c|}{ Publication Year } & $\begin{array}{c}\text { Pre-selected Step } \\
\mathbf{0 2}\end{array}$ & $\begin{array}{c}\text { Pre-selected Step } \\
\mathbf{0 1}\end{array}$ & Selected \\
\hline $\mathbf{2 0 1 4 - 2 0 1 6}$ & 6 & 3 & 3 \\
\hline $\mathbf{2 0 1 7 - 2 0 1 9}$ & 6 & 3 & 1 \\
\hline $\mathbf{2 0 2 0}$ & 5 & 3 & 1 \\
\hline Previous Dates & 3 & 2 & 1 \\
\hline Total works & 20 & 11 & 6 \\
\hline
\end{tabular}

From the texts found in the search process on academic platforms, 20 tasks were pre-selected in the first reading step, in the second step, 11 articles were selected 
that versed about projects with using the internet of things for smart parking. Of these, only 6 brought pertinent contributions for use in the covered environments.

The technologies and architectures used in the selected texts are discussed, followed by how they could assist in the design of a new architecture, in which there is the integration of different systems to direct the user to the parking space, as well as in the process of return to the vehicle.

\section{DISCUSSION AND RESULTS}

In the project created by [3], ultrasonic sensors are used to detect whether the parking space is occupied or free. Independent wireless networks were used for the acquisition and transmission of data with a specific communication module, responsible for sending and receiving local information by radio frequencies, which later transport the local information to a Raspberry Pi microcomputer. This, in turn, carried out the processing of the parking spaces situation to feed the database and cloud, which made such information available to customers. The concern in this approach is to count the number of parking spaces and make information available via mobile application, but it does not link to the possibility of directing the user to the exact place to park his vehicle.

In the system planned by [7], three infrared sensors measure the length of the vehicle when it stops at the parking gate. At that moment, two variables are considered: the size of the car and the shortest distance that separates the vehicle from a parking space. The parking arrangement separates vehicles in "class" from sizes. The method used by the researchers is relevant in spaces where there are variations in the size of the parking spaces, since it uses such a metric to direct the driver to the most appropriate place for the structure of the space. To implement the project, they used the Proteus software with the library for programming on Arduino microcontroller that manages the system with the help of the Dijkstra algorithm. This algorithm has the advantage of finding the shortest distance between two points when a reference point is known. While infrared sensors are used to determine the vehicle's allocation in a parking space, the project under development will use Bluetooth to determine the stop location and subsequent management of the information that will serve as information for the Client / server set.

[8] developed a parking system that is expected to be used both indoors and outdoors. For this, they realized the installation of two types of sensors associated with BLE (Bluetooth Low Energy - low consumption bluetooth) for sending, receiving and communicating with users. Indoors, ultrasonic sensors are installed in conjunction with the BLE in each parking space and in the external environment there is the use of magnetic sensors also installed in conjunction with the BLE. Part of the approach suggested by [8] will be used for the development of the proposed architecture, to link the customer with the parking space. A unique record will be generated for directing the customer to the parking space at the time when arriving at the parking lot and in the process of returning to the parking space where the car parked.

[9] propose in their work an architecture similar to that of the authors previously presented, however the main difference of their system is linked to navigation, since it allows the user to interact in two different stages and environments. The first happens 
when the navigation is accessed to direct the driver from any place to the parking, this process is developed with the union of GPS location and a cell phone application. The second stage begins with the arrival at the parking lot and the system recognizes the user and their vehicle through an RFID label, at that moment there is an automatic exchange of navigation in the application, from GPS to a network of bluetooth devices, which uses RSSI (Received Signal Strength) as a navigation parameter. The interaction between the systems is of great use for the development of intelligent systems, in this context the indication of the navigation mapping through the RSSI measurements will be used as user's guidance to the parking space in both moments, a) direct to the parking space and b) guide the user to the parked vehicle.

[10] created a system that interacts with the client through a mobile application through which the user chooses a parking space and is directed to it by GPS navigation. Despite allowing the driver to return to his vehicle, through a WLAN network (Wireless Local Area Network) and RSSI measurements to determine the user's location and direct him to the vehicle, this system works only in open-air parking. Thus, the metric used, even for open-air parking, corroborates the work when using WLAN networks for frequency mapping, which also allows the user to be directed to the environment in which the vehicle is parked.

In the project developed by [11], a system is created that interacts directly with the user through an Android application that records the information obtained by the existing sensors in the cell phone: accelerometer, gyroscope, magnetometer, barometer and orientation sensors. After the user starts recording in the developed application, the generation of the map will start, which will record the user's entire journey and at the end it will indicate the return path to the user, but along the same path that the user took during the entire stay in the environment.

In general, it is clear that the above approaches are in consonance with the proposition of the new architecture, although they work in different ways and with punctual resolutions of the process involving smart parking systems in covered environments.

\section{DESCRIPTION OF THE PROPOSED ARCHITECTURE}

The system to be developed takes into account the contributions of the authors mentioned, but considers the mapping and return approach carried out in a different way. This project proposal is divided into four phases, explained next, and is based on the architecture representation present in figure 2.

The first stage is responsible for identifying the user on arrival at the parking using bluetooth pairing, which will be recorded in the database, developed in MySQL, and later in the cloud through Wi-Fi.

The second stage will perform a search on the parking space registered in the database, in order to identify which are vacancies to indicate a location to the user and afterwards guide the customer to the location. In the proposed system, the best path shall be addressed to the customer, considering the distance between the location where the user is and the parking space where the vehicle was parked. 
The third step will create a link between the user and the "real stop" location, as the customer may not directly follow the instructions and allocate his vehicle in a different parking space from the one initially indicated by the system.

Finally, when the user wants to return to his vehicle, the system must identify which part of the establishment the customer is in, generate a route calculating the shortest route and direct him to the place where the vehicle is parked.

Figure 2. Proposed architecture (by the authors).

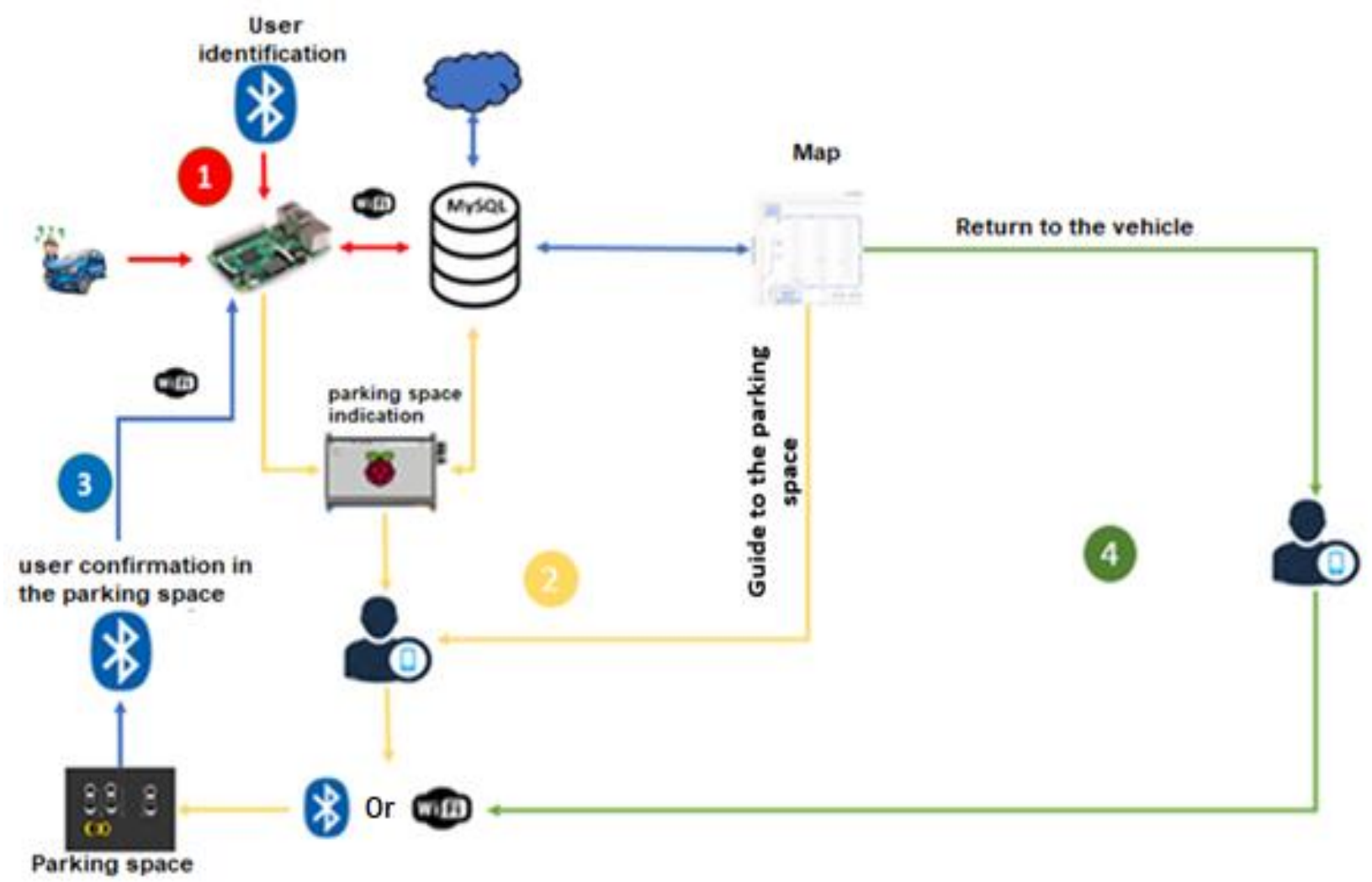

\section{CONCLUSION}

The creation of a new architecture for the development of systems with greater interaction between User / server was promoted through the identification of existing gaps in the academic works available on the search platforms, such gaps serve as support to the expansion of characteristics linked to smart systems for closed parking.

Soon, the proposed architecture takes on the theme in order to remedy potential problems related to the search for a parking space, linking the customer and vehicle with a parking lot, mapping the location through the frequencies emitted by BLE or WiFi devices, intelligent management of the occupation of the environment, in addition to guiding users from the arrival at the parking until the return to the place where the vehicle was parked. Process that motivates and promotes relevance to the proposed architecture during the development of the new smart parking system for indoor environments. 


\section{Acknowledgments}

The present work was carried out with the support of the Improvement Coordination of Higher Education Personnel - Brazil (CAPES) - (Process number: 88882.452863 / 2019-01) and the professors of the Post-graduate course in Mechatronics at the Federal University of Bahia.

\section{REFERÊNCIAS}

[1] DORNELAS, E.; CAMPELLO, S. Monitoramento de consumo doméstico de água utilizando uma meta-plataforma de loT. Revista de Engenharia e Pesquisa

Aplicada, v. 2, n. 2, p. 136-147, 2017.

[2] FERREIRA, A. DE Á. Estratégias e iniciativas para a mobilidade em cidades inteligentes. Porto Alegre: UNIVERSIDADE FEDERAL DO RIO GRANDE DO SUL, 2016.

[3] CAVAMURA, Humberto Fernando Massaharu; MITSUHASHI, Marlos Kenjy. Sistema de gerência de vagas de estacionamento. 2014. Trabalho de Conclusão de Curso. Universidade Tecnológica Federal do Paraná.

[4] HASSOUNE, Khaoula et al. Sistemas de estacionamento inteligentes: uma pesquisa. In: 2016 11th International Conference on Intelligent Systems: Theories and Applications (SITA). IEEE, 2016. p. 1-6.

[5] RONSANI, Luiz Antonio Kuhnen. Um protótipo de sistema inteligente para monitoramento de vagas de estacionamentos-Uma aplicação baseada em Internet das Coisas. 2018.

[6] KHANNA, Abhirup; ANAND, Rishi. IoT based smart parking system. In: 2016 International Conference on Internet of Things and Applications (IOTA). IEEE, p. 266-270, 2016.

[7] ATA, KI Mohammad et al. Smart Indoor Parking System Based on Dijkstra's Algorithm. International Journal of Electrical Engineering and Applied Sciences (IJEEAS), v. 2, n. 1, p. 13-20, 2019.

[8] LEE, Chungsan et al. Smart parking system for Internet of Things. In: 2016 IEEE International Conference on Consumer Electronics (ICCE). IEEE, p. 263-264, 2016. 
[9] TSAI, Ming-Fong; KIONG, Ye Chin; SINN, Ang. Smart service relying on Internet of Things technology in parking systems. The Journal of Supercomputing, v. 74, n. 9, p. 4315-4338, 2016.

[10] LIU, Jingbin et al. iParking: An intelligent indoor location-based smartphone parking service. Sensors, v. 12, n. 11, p. 14612-14629, 2012.

[11] FATHY, Heba; ELBASIONY, Reda; FAHEEM, Mohamed Talaat. Finding a Parked Car Location in a Multi-Storey Building Without GPS Service. International Journal of Interactive Mobile Technologies, v. 14, n. 10, 2020. 